\title{
Indirect spectrophotometric determination of paracetamol via oxidative coupling reaction with 4-(2-pyridylazo)-resorcinol
}

\author{
Thabit S. Al-Ghabsha Theia'a N. Al-Sabha Amal M. Saeed \\ Chemistry department, college of Education \\ Mosul University \\ Mosul, Iraq
}

Received Accepted

5/12/2005 6/10/2005

\begin{abstract}
الخلاصــــة
تم وصف طريقة طيفية سهلة وســريحة وحساسة لتقدير كميـات ضــيلة مسن

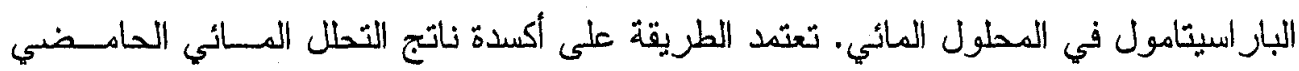

للبار اسيتامول بواسطة بيريودات البوتاسيوم و واقتزانه مع الكاشـــ 4-(2-بريسديل أزو)

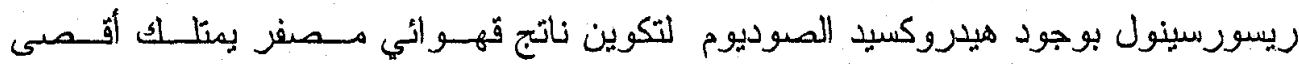

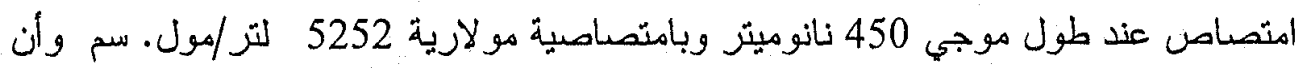

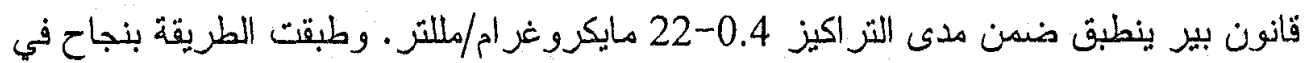

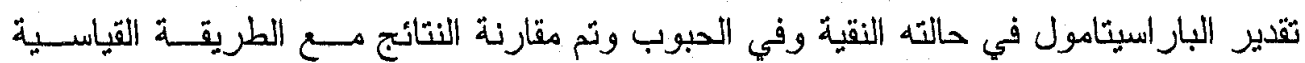

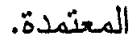

\begin{abstract}
A rapid, sensitive and simple spectrophotometric method is proposed for the determination of paracetamol. The method is based on the oxidation of the hydrolytic product of paracetamol by potassium periodate and coupled with 4-(2-pyridylazo)-resorcinol in the presence of sodium hydroxide. The absorbance of the yellowish-brown product is measured at $450 \mathrm{~nm}$ and the molar absorptivity found to be $52521 . \mathrm{mol}^{-}$ ${ }^{1} . \mathrm{cm}^{-1}$. The product conforms to Beer's law over the range $0.4-22.0 \mu \mathrm{g} \mathrm{ml}{ }^{-}$ 1. The method is successfully employed for assay of paracetamol in tablets and results have been compared with those obtained by the official method.
\end{abstract}

Keywords: Paracetamol; oxidative coupling; spectrophotometry. 


\section{Introduction}

Paracetamol (N-acetyl-p-aminophenol or acetaminophen) is an effective analgesic and antipyretic agent. p-Aminophenol is the hydrolytic product of paracetamol and is reported to have significant nephrotoxicity and teratgenic effects [1].

Numerous spectrophotometric methods have been reported for the determination of paracetamol after its hydrolysis to p-aminophenol in pure form, pharmaceutical preparations and biological fluids, using several coupling reagents such as 8-hydroxyquioline[2], o-cresol [3] and p-xylenol [4] in the presence of sodium periodate as oxidizing agent. Thymol has been used as coupling reagent for the determination of paracetamol and its hydrolytic product in the presence of sodium metaperiodate[5], cerium(IV)sulphate[6] and potassium dichromate[7] as oxidizing reagents. Also; charge transfer complexes using chloranil [8], 2,3-dichloro-5,6-dicyano-p-benzoquinone [9] and bromanil [10] as $\pi$ acceptors have been employed indirectly for the spectrophotometric determination of paracetamol. Azo-dye formation reactions have also been used for the indirect spectrophotometric determination of paracetamol [11,12], Moreover, derivative[13] and differential [14] spectroscopic methods have been described for the determination of paracetamol. Copper-NTA complex is used for determination of paracetamol by its enhancement the sensitivity of the this complex[15]. Near-infrared (NIR) reflectance spectroscopy was used to determine the content of paracetamol in bulk batches of intact Sterwin $500 \mathrm{mg}$ tablets by collecting NIR spectra in the range 1100-2500 nm and using a multiple linear regression calibration method[16].A flow injection method is described for determination of paracetamol in pharmaceutical dosage forms based on the nitration of paracetamol with sodium nitrite, and the absorption of the product was measured at $430 \mathrm{~nm}$ in alkaline medium[17]. Some of these procedures suffer from interferences from other active ingredients or additives especially those carrying phenolic or amine functional groups.

The present work describes an indirect spectrophotometric method for assay of paracetamol in pharmaceutical preparations based on oxidative coupling reaction with 4-(2-pyridylazo)-resorcinol reagent in the presence of potassium periodate and sodium hydroxide.

\section{Experimental Apparatus}

All spectral absorbance measurements were carried out on Shimadzu (UV-210) Double-beam Spectrophotometer using 1-cm silica cells. 


\section{Reagents}

All chemicals used were of analytical reagent grade and paracetamol standard material was provided from the State Company for Drug Industries and Medical Appliances, Sammara-Iraq. 4-(2-Pyridylazo)-resorcinol solution: $1 \times 10^{-3} \mathrm{M}$ prepared by dissolving $0.1366 \mathrm{~g}$ of 4-(2-pyridylazo)-resorcinol monosodium dehydrate (Hopkins $\&$ Williams ) in distilled water and then the solution was made up to 500 $\mathrm{ml}$ in volumetric flask with the same solvent and kept in amber bottle. This solution is stable at least for two weeks.

Potassium periodate solution: $0.01 \mathrm{M}$ prepared by dissolving $0.230 \mathrm{~g}$ of potassium periodate in distilled water and complete the volume to $100 \mathrm{ml}$ in volumetric flask with distilled water.

Sodium hydroxide solution: $0.1 \mathrm{M}$ prepared by dissolving $0.4 \mathrm{~g}$ of sodium hydroxide in $100-\mathrm{ml}$ volumetric flask and complete the volume to the mark with distilled water.

Paracetamol solution :2000 $\mathrm{gmll}^{-1}$ prepared by dissolving $0.2 \mathrm{~g}$ of pure paracetamol powder in $10 \mathrm{ml}$ of ethanol and the solution was made up to $100 \mathrm{ml}$ in a volumetric flask with distilled water.

Stock solution of hydrolyzed paracetamol $\left(100 \mu \mathrm{g} \mathrm{ml} l^{-1}\right)$

Accurately $75 \mathrm{ml}$ of $2000 \mu \mathrm{g} \mathrm{ml}^{-1}$ paracetamol was transferred into $250 \mathrm{ml}$ conical flask provided with condenser, add $25 \mathrm{ml}$ of $11.8 \mathrm{M} \mathrm{HCl}$ and refluxed for 1 hour. Then cooled and the solution was neutralized by $20 \% \mathrm{Na}_{2} \mathrm{CO}_{3}$ and diluted to $250 \mathrm{ml}$ with distilled water in a volumetric flask, then $16.7 \mathrm{ml}$ of this solution was transferred to $100 \mathrm{ml}$ volumetric flask and complete the volume with distilled water to obtain a concentration of $100 \mu \mathrm{g} \mathrm{ml}^{-1}$.

\section{Preparation of tablet samples}

Weighed and finely powdered 10 tablets. An accurately weighed amount of powder equivalent to $0.2 \mathrm{~g}$ of paracetamol was transferred into $100 \mathrm{ml}$ calibrated flask, dissolved in $5 \mathrm{ml}$ of ethanol and complete the volume with distilled water. Filtered through a Whatmann 41 filter paper, and proceed the procedure as the stock solution of hydrolyzed paracetamol.

\section{General assay procedure}

Transfer different amounts of hydrolyzed paracetamol standard sample solution into a series of $25-\mathrm{ml}$ volumetric flasks covering the range $0.4-22.0 \mu \mathrm{g} \mathrm{ml}^{-1}$ in final volume. Add $3 \mathrm{ml}$ of 4-(2-pyridylazo)resorcinol reagent solution followed by $1 \mathrm{ml}$ of potassium periodate solution and $1 \mathrm{ml}$ of sodium hydroxide, then dilute to the mark with distilled water. Stopper the flasks and shake well, then allow them to 
stand for $20 \mathrm{~min}$ at room temperature, and the absorbance is measured at $450 \mathrm{~nm}$ against the reagent blank.

\section{Results and discussion}

\section{Absorption spectra}

p-Aminophenol (the hydrolyzed product of paracetamol) was allowed to react with 4-(2-pyridylazo)-resorcinol in the presence of potassium periodate as an oxidizing reagent and sodium hydroxide to produce a yellowish-brown colour with maximum absorption at $450 \mathrm{~nm}$ while the reagent blank shows low absorption at this wavelength (Fig.1).

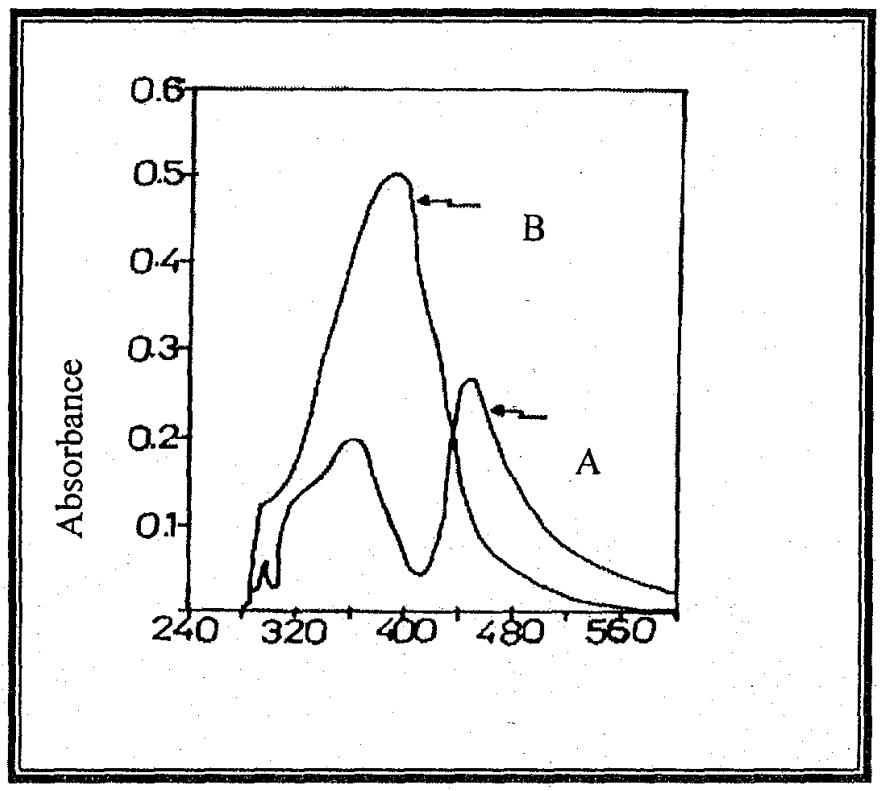

Wavelength. nm

Fig.1 Absorption spectra of (a) $2 \mathrm{ml}$ of $100 \mu \mathrm{g} \mathrm{ml}^{-1}$ hydrolyzed paracetamol with $3 \mathrm{ml}$ of $\quad 1 \times 10^{-3} \mathrm{M} 4$-(2-pyridylazo)-resorcinol and $1 \mathrm{ml}$ of $0.01 \mathrm{M}$ potassium periodate solution and $1 \mathrm{ml}$ of sodium hydroxide in final volume of $25-\mathrm{ml}$ versus blank, and(b) $3 \mathrm{ml}$ of $\quad 1 \times 10^{-3} \mathrm{M}$ 4-(2-pyridylazo)- resorcinol in final volume of $25-\mathrm{ml}$ versus distilled water.

\section{Effect of amounts of potassium periodate}

Increasing volumes of $0.01 \mathrm{M}$ potassium periodate are added to the fixed amounts of hydrolytic product of paracetamol $(8 \mathrm{Hg} / \mathrm{ml})$ and $\mathrm{NaOH}$ solution $(1 \mathrm{ml}$ of $0.1 \mathrm{M})$. It was found that $1 \mathrm{ml}$ of potassium periodate gave maximum colour intensity which is used in all subsequent experiments. 


\section{Effect of $\mathrm{pH}$ and buffers}

The effect of $\mathrm{pH}$ ranged from 4 to 12 on the absorption of the product was studied using different concentrations of $\mathrm{HCl}$ and $\mathrm{NaOH}$. It was found that the product formed in the final $\mathrm{pH}$ of 9 using $0.1 \mathrm{M}$ of $\mathrm{NaOH}$ (Table1). Therefore different buffers of $\mathrm{pH}_{9}$ are prepared such as phosphate, borate and carbonate to examine the sensitivity. It was found that the these buffers decrease the absorbance (Table2).

Table 1. Effect of $\mathrm{pH}$ on the absorption of the product

\begin{tabular}{|c|c|c|c|c|c|c|c|c|}
\hline (3) & 4 & 6 & 7 & 8 & 9 & 10 & 11 & 12 \\
\hline & 0.173 & 0.192 & 0.209 & 0.267 & 0.280 & 0.251 & 0.249 & 0.223 \\
\hline
\end{tabular}

Table 2: Effect of buffers on the absorption of the product

\begin{tabular}{|c|c|}
\hline Burcts & \\
\hline Without* & 0.201 \\
\hline Phosphate & 0.234 \\
\hline Borate & 0.224 \\
\hline Carbonate & 0.216 \\
\hline Sodium hydroxide & 0.280 \\
\hline
\end{tabular}

*Without addition of buffer or sodium hydroxide

\section{Effect of $\mathrm{NaOH}$ concentration}

Increasing volumes of $0.1 \mathrm{M} \mathrm{NaOH}$ are added to the fixed amounts of hydrolytic product of paracetamol $(8 \mu \mathrm{g} / \mathrm{ml})$ and $\mathrm{KIO}_{4}(1 \mathrm{ml}$ of $0.01 \mathrm{M})$. As shown in table 3 it was found that $1 \mathrm{ml}$ of $\mathrm{NaOH}$ gave high absorbance and used in all subsequent experiments.

Table 3: Effect of $\mathrm{NaOH}$ concentration on the absorption of the product

\begin{tabular}{|c|c|c|c|c|c|c|}
\hline (56) & 0.3 & 0.5 & 0.7 & 1.0 & 1.3 & 1.5 \\
\cline { 2 - 6 } & 0.235 & 0.243 & 0.262 & 0.281 & 0.260 & 0.257 \\
\hline
\end{tabular}

\section{Effect of 4-(2-pyridylazo)-resorcinol concentration}

The effect of different 4-(2-pyridylazo)-resorcinol concentrations on the absorbance of solution containing $8 \mu \mathrm{gml}^{-1}$ hydrolyzed paracetamol was studied. It is evident that the absorbance increases with increasing 4(2-pyridylazo)-resorcinol concentration and reached maximum on using 
$3 \mathrm{ml}$ of $1 \times 10^{-3} \mathrm{M} 4$-(2-pyridylazo)-resorcinol. Therefore, this concentration was used in all subsequent work.

\section{Effect of temperature and reaction time}

The reaction time was determined by following the colour development at room temperature and in thermostatically controlled water-bath adjusted at 0,40 and $50^{\circ} \mathrm{C}$. The absorbance was measured at $5 \mathrm{~min}$ intervals against reagent blank treated similarly. It was observed that the absorbance reached maximum after $20 \mathrm{~min}$ at room temperature and remains constant more than 6 hours and the absorbance decreased slowly thereafter. Hence room temperature and reaction time $(20 \mathrm{~min})$ were chosen for colour development.

\section{Effect of order of addition}

The effect of order of addition on the absorbance of the product was studied under the optimum experimental conditions, and the results are shown in the table(4) indicating that the product is formed with high sensitivity by the following order:

Hydrolyzed paracetamol + 4-(2-pyridylazo)-resorcinol + potassium periodate + sodium hydroxide

Table 4: Effect of order of addition

Assuming that:

\begin{tabular}{|l|l|}
\hline Orkes & \\
\hline $\mathrm{S}+\mathrm{R}+\mathrm{B}+\mathrm{O}$ & 0.270 \\
\hline $\mathrm{S}+\mathrm{R}+\mathrm{O}+\mathrm{B}$ & 0.280 \\
\hline $\mathrm{O}+\mathrm{S}+\mathrm{R}+\mathrm{B}$ & 0.275 \\
\hline $\mathrm{O}+\mathrm{R}+\mathrm{S}+\mathrm{B}$ & 0.264 \\
\hline $\mathrm{B}+\mathrm{O}+\mathrm{S}+\mathrm{R}$ & 0.269 \\
\hline $\mathrm{B}+\mathrm{O}+\mathrm{R}+\mathrm{S}$ & 0.227 \\
\hline $\mathrm{R}+\mathrm{O}+\mathrm{B}+\mathrm{S}$ & 0.221 \\
\hline $\mathrm{S}+\mathrm{O}+\mathrm{B}+\mathrm{R}$ & 0.274 \\
\hline
\end{tabular}

$\mathrm{S}=$ sample, $\mathrm{R}=$ reagent, $\mathrm{B}=$ base, $\mathrm{O}=$ oxidizing agent

\section{Quantitation}

Under the proposed experimental conditions, a linear relation between the absorbance and concentration of hydrolyzed paracetamol was observed over the concentration range $0.4-22.0 \mu \mathrm{g} \mathrm{ml}^{-1}$ (Fig.2), with correlation coefficient of 0.999 and intercept of 0.03406 . A negative deviation from Beer's law was observed at higher concentrations of paracetamol. The molar absorptivity is $52521 . \mathrm{mol}^{-1} . \mathrm{cm}^{-1}$. 


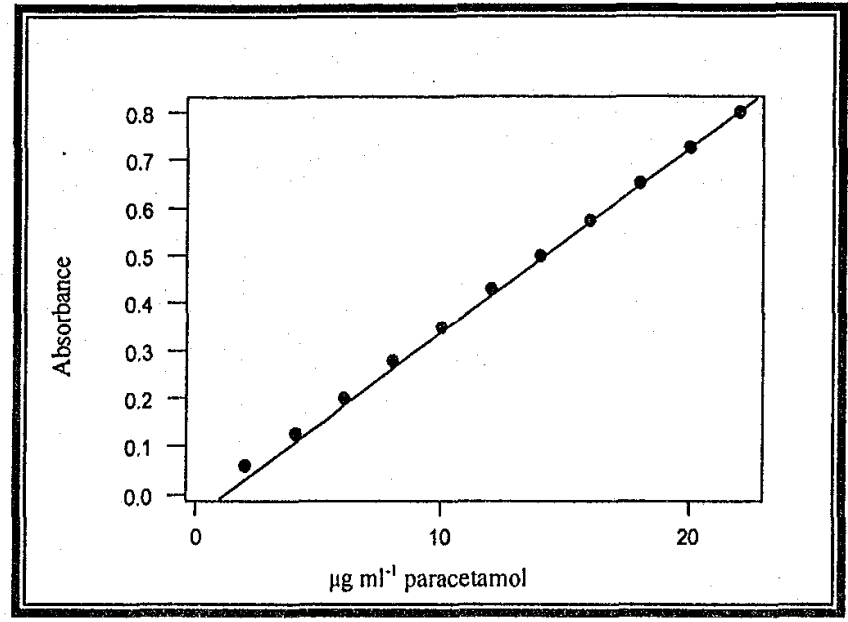

Fig.2 Calibration graph of hydrolyzed paracetamol

\section{Accuracy and precision}

To determine the accuracy and precision of the method, paracetamol was determined at three different concentrations. The results shown in table(5) referring a satisfactory precision and accuracy.

Table 5: Accuracy and precision of the proposed method

\begin{tabular}{|c|c|c|}
\hline 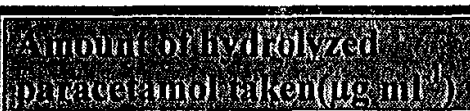 & 16. & 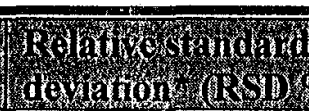 \\
\hline 8 & 100.53 & 0.234 \\
\hline 12 & 100.58 & 0.230 \\
\hline 16 & 99.50 & 0.172 \\
\hline
\end{tabular}

*Average for six determinations

\section{Interferences}

In order to assess the possible analytical applications of the proposed method, the effect of some common excipients usually found with paracetamol drug in pharmaceutical formulations, such as acacia, glucose, lactose, starch, sodium chloride and magnesium stearate was studied by analyzing synthetic sample solutions containing $10 \mu \mathrm{g} / \mathrm{ml}$ of paracetamol and excess amounts (10-fold excess) of each excipient, none of these substances interfered seriously (Table 6). 


\begin{tabular}{|c|c|c|}
\hline 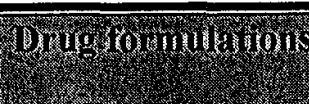 & 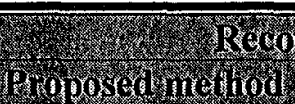 & Standhad mothody \\
\hline Paracetamol tablet & 99.23 & 101.0 \\
\hline Algesic tablet & 101.13 & 99.0 \\
\hline Dolo tablet & 100.32 & 99.7 \\
\hline Colden tablet & 100.70 & 100.9 \\
\hline
\end{tabular}

British Pharmacopoeia (standard method) [19]

\section{Conclusion}

Indirect spectrophotometric method has been proposed for the determination of paracetamol in pure form. It has been shown that the proposed method is rapid, simple and sensitive for the assay of paracetamol in its pharmaceutical tablets without interference from commonly used excipients.

\section{References}

1. Mohamed F.A., AbdallAllah M.A. and Shammat S. M., Talanta, 44,61-68, (1997).

2. Bouhsain Z., Grrigues S. and Morales A, Anal.Chim.Acta, 330,59, (1996).

3. Craido A., Cardenas S. and Callego M., Talanta,53,417, (2000).

4. Afshari J.T. and Lino T.Z., Anal.Chim.Acta, 443, 165,(2001).

5. Al-Ward H.S.J., "Analytical pharmaceutical applications on oxidative coupling reaction", M.Sc.Thesis, University of Baghdad. (2002).

6. Sultan S.M., Al-Zamil I.Z. and Al-Rahman A.M.A, Analyst, $11,919,(1986)$.

7. Sultan S.M., Talanta, 34, 605, (1987).

8.Al-Ghabsha T.S., Al-Abachi M.Q. and Ahmad A.K., Microchem.J., 35,66,(1987).

9. Al-Enizzi M.S.,"Development of spectrophotometric method for the determination of paracetamol,histamine and some sulpha drugs", M.Sc. thesis, Mosul University,(2002).

10. Jarallah S. M., The use of charge-transfer complex formation reaction in the spectrophotometric determination of some amines and drug compounds, Ph.D. Thesis, University of Mosul, (2004).

11. Belal S.F.,El-Sayed A.H. and El-Waily A,Pharm.Sci.,68,750, (1979).

12. Gesso S.G., "Development of spectrophotometric method for trace determination of some organic compounds in pharmaceutical preparations", M.Sc.Thesis, University of Mosul, (1991). 
13. Sharaf El-Din M. K., Abuijeie M. A. and Abdel Hay M. H., Anal. Lett.,24, 2187, (1991).

14. El-Kheir A.A., Belal S. and El-Shanawani, Pharmazie, 40, 62,(1985).

15. Al-Ghabsha T.S., Al-Sabha T.N. and Saeed A.M., J. Educ.and Sci., Article in the press.

16. Andrew D. Trafford, Roger D. Jee, Anthony C. Moffat and Paul Graham Analyst, 124, 163-167,(1999).

17. Knochen M., Giglio J. and Ries B.F., J.Pharm.and Biomed.Analysis, 33,191-197,(2003).

18.Christian G.D., Analytical Chemistry, fifth ed., Wiley, New York, (1994), pp.385-386.

19. British Pharmacopoeia, vol. 7,(2000), part 62-6. 